\title{
ONOMATOPE BAHASA MANDARIN DALAM KOMIK
}

\author{
Yang Nadia Miranti, David Vincensius \\ Program Studi Sastra Cina Fakultas IImu Budaya \\ Universitas Brawijaya \\ Email: yangnadia@ub.ac.id, davidvincensius@student.ub.ac.id
}

\begin{abstract}
Abstrak
Sebagai karya sastra bergambar, komik memiliki hubungan yang erat antara seni gambar dan seni berbahasa. Kedua unsur tersebut merupakan satu kesatuan yang saling membangun untuk membentuk komik menjadi sebuah karya yang dapat dinikmati masyarakat. Seni gambar yang indah dan didukung dengan gaya bahasa yang baik, akan mampu menciptakan sebuah cerita komik yang menarik. Gaya berbahasa dalam komik tentunya tidak hanya bentuk baku atau berupa peribahasa, melainkan juga harus mampu menyesuaikan keadaan latar dalam cerita tersebut. Penyesuaian ini salah satunya diwujudkan melalui penerapan onomatope.

Melalui onomatope, pemaknaan sebuah kalimat akan mampu menghidupkan emosi pembaca. Onomatope ada dalam setiap bahasa, termasuk bahasa Mandarin. Penelitian ini akan membahas onomatope dalam tiga komik berbahasa Mandarin, yaitu 大雄的大魔镜 Dàxióng De Dà Mó Jìng, 长歌行 Zhăng Gē Xíng, dan 白木兰圆舞曲 Bái Mùlán Yuánwǔqǔ. Berdasarkan penelitian ini, ditemukan bahwa onomatope bahasa Mandarin dalam komik, berhasil meningkatkan emosi pembaca dalam mewujudkan kata tiruan dari bunyi suara manusia, binatang, alam, benda, kegiatan sehari-hari dan alat musik. Adanya respon pembaca dari sebuah karya sastra merupakan tanda bahwa karya tersebut telah berhasil dinikmati dan mampu memberikan kesan.
\end{abstract}

Kata kunci : Onomatope, Bahasa Mandarin, Komik

\begin{abstract}
As a pictorial literary work, comics have a close relationship between drawing and language arts. These two elements form a unity that builds each other up to form comics into works that can be enjoyed by the public. Beautiful drawing art and supported by a good language style, will be able to create an interesting comic story. The language style in comics is of course not only a standard form or in the form of a proverb, but also must be able to adjust the setting in the story. One of these adjustments is realized through the application of onomatopoeia.

Through onomatopoeia, the meaning of a sentence will be able to turn on the reader's emotions. Onomatopoeia is in every language, including Chinese. This research will discuss onomatopoeia in three Chinese comics, namely 大雄的大魔镜Dàxióng De Dà Mó Jìng, 长歌行 Zhăng Ge Xíng and 白木兰圆舞曲 Bái Mùlán Yuánwǔqǔ. Based on this research, it was found that the Mandarin onomatopoeia in comics succeeded in increasing the readers' emotions in realizing imitation words from the sounds of human sounds, animals, nature, objects, daily activities and musical instruments. A reader's response to a literary work is a sign that the work has been successfully enjoyed and is able to make an impression.
\end{abstract}

Key Words: Onomatopoeia, Mandarin language, Comic 


\section{A. PENDAHULUAN}

Onomatope atau dalam bahasa Mandarin disebut dengan 象声词 xiàngshēngcí merupakan satu kajian ilmu bahasa yang membahas terkait kata tiruan bunyi suatu suara. Menurut Asworth (2012, hal. 22) Onomatopoeia is using words to represent sound. We're not talking about adjective (loud, annoying, strange). When you use onomatopoeia, you actually give a sound its own word. Berdasarkan pengertian ini, dapat diketahui bahwa onomatope bukan kata sifat atau kata yang memiliki kedudukan sebagai suatu makna fungsional, melainkan merupakan suara suatu bunyi, sehingga suatu bunyi yang kita dengar dapat dideskripsikan menjadi suatu kata dan bahkan dapat ditulis. Onomatope merupakan suatu unsur penting dalam ilmu bahasa karena memberikan suasana tersendiri dalam karya sastra. Melalui onomatope, suatu karya sastra dapat menjadi lebih hidup dan dapat dinikmati pembaca secara nyata. Khususnya dalam karya komik. Menurut Gumelar (2011, hal. 7) menyampaikan bahwa komik adalah urutan-urutan gambar yang ditata sesuai tujuan dan filosofi pembuatnya hingga pesan cerita tersampaikan. Hal ini mengartikan bahwa unsur utama pembentuk karya komik ada seni gambar dan berbahasa. Selain itu, Nurgiyantoro (2018, hal. 417) juga menjelaskan bahwa hakikat komik adalah perpaduan antara gambar dan bahasa, aspek visual dan aspek verbal. Aspek visual bermakna melalui indra penglihatan dan aspek verbal melalui ucapan. Perpaduan ini sangat penting karena dapat membuat karya komik semakin menarik untuk dikonsumsi.

Penelitian ini menggunakan tiga komik bahasa Mandarin, yakni 大雄的大魔镜 Dàxióng De Dà Mó Jìng, 长歌行 Zhăng Gē Xíng dan 白木兰圆舞曲 Bái Mùlán Yuánwǔqǔ. Komik 长歌行 zhăng gē xíng atau dalam bahasa Inggris dikenal dengan Song of the Long March karya 夏达 Xià Dá adalah komik yang bertemakan sejarah pada masa dinasti Tang. Komik ini bercerita tentang petualangan seorang putri setelah berhasil melarikan diri dari upaya pembunuhan pada seluruh anggota keluarganya. Komik ini memulai serialisasinya pada Februari 2011 oleh Comic Fans. Komik yang masih berlanjut hingga saat ini tergolong dalam jenis komik aksi, petualangan dan drama. Selain itu, penelitian ini juga menggunakan komik 大雄的大魔镜 Dàxióng De Dà Mó Jìng sebagai objek penelitian lainnya. Komik ini menceritakan petualangan 哆啦 $\mathrm{A}$ 梦 Duōlaamèng, 大 雄 Dàxióng, 胖 虎 Pànghǔ, 小夫 Xiăofū dan 静香 Jìngxiāng, bersama anjing misterius bernama 扁扁 Biănbiăn. Mereka berpetualang ke negeri misteri yang terletak di pedalaman benua Afrika. Anjing misterius yang dibawa oleh 大雄 Dàxióng ternyata adalah pangeran di negeri misterius tersebut yang ingin memberantas kejahatan dan merebut kembali kerajaannya. 大 雄 Dàxióng dan kawan-kawannya membantu 扁 扁 Biănbiăn untuk mewujudkan keinginannya. Sedangkan komik 白木兰圆舞曲 Bái Mùlán Yuánwǔqǔ bercerita terkait perjuangan serta kesenian, Ketiga komik ini dipilih sebagai objek penelitian karena memiliki banyak penggemar dari berbagai negara. Selain menyuguhkan gambar yang indah dan mudah dipahami, komik-komik ini juga memberikan pengetahuan sejarah melalui ceritanya serta meningkatkan daya imajinasi pembacanya.

\section{B. METODOLOGI}

Peneliti menerapkan metode penelitian kualitatif untuk melaksanakan penelitian ini. Menurut Widi (2010: 57) studi digolongkan sebagai penelitian kualitatif bila tujuan utama studi tersebut adalah untuk menggambarkan situasi, fenomena, permasalahan atau kejadian. Peneliti secara langsung membaca objek penelitian kemudian menganalisis 
kata onomatope di dalamnya dengan penerapan teori onomatope. Peneliti menggabungkan kegiatan studi pustaka dan studi lapangan. Putri (2019:40) mengungkapkan studi pustaka berkaitan dengan kajian teoritis dan beberapa referensi yang tidak akan lepas dari literatur-literatur ilmiah. Metode studi lapangan menurut Langelo, dkk. (2015 : 4) digunakan untuk mengetahui seberapa jauh kesesuaian antara teori yang digunakan dengan keadaan yang sebenarnya dari objek yang diteliti. Perpaduan kedua kegiatan tersebut membantu peneliti mendapatkan hasil terkait penerapan onomatope bahasa Mandarin dalam komik secara maksimal.

\section{HASIL DAN PEMBAHASAN}

Onomatope Suara Manusia

\begin{tabular}{|l|l|l|}
\hline No. & \multicolumn{1}{|c|}{ Onomatope } & \multicolumn{1}{|c|}{ Makna } \\
\hline 1 & 呜啊 $w \bar{u} \bar{a}$ & $\begin{array}{l}\text { Menunjukkan suara seseorang yang didorong hingga } \\
\text { terjatuh dari kereta. }\end{array}$ \\
\hline 2 & 哇啊啊啊啊 $w \bar{a} \bar{a} \bar{a} \bar{a}$ & $\begin{array}{l}\text { Menunjukkan seorang anak yang berlari sambil } \\
\text { berteriak. }\end{array}$ \\
\hline 3 & 啧 zé & Tiruan bunyi decak lidah. \\
\hline 4 & 皮 $b \bar{o}$ & $\begin{array}{l}\text { Menunjukkan suara seseorang yang kagum dengan } \\
\text { harta benda yang dilihatnya. }\end{array}$ \\
\hline 5 & 呜喔喔喔喔 $w \bar{u} \bar{o} \bar{o} \bar{o}$ & $\begin{array}{l}\text { Menunjukkan teriakan seorang prajurit karena } \\
\text { diserang secara mendadak. }\end{array}$ \\
\hline 6 & 呜 $w \bar{u}$ & Menunjukkan suara seorang prajurit yang ketakutan. \\
\hline 7 & 哈哈哈哈 $h \bar{a} h \bar{a} h \bar{a} h \bar{a}$ & Menunjukkan suara tawa. \\
\hline 8 & 呼 $h \bar{u}$ & $\begin{array}{l}\text { Menunjukkan bunyi nafas terengah-engah saat } \\
\text { berlari. }\end{array}$ \\
\hline 9 & 啪啪 $p \bar{a} p \bar{a}$ & $\begin{array}{l}\text { Menunjukkan suara baju yang dipukul-pukul untuk } \\
\text { membersihkan debu yang menempel. }\end{array}$ \\
\hline 10 & 呜哇哇 $m a w \bar{a} w \bar{a}$ & Menunjukan suara teriakan karena terkejut. \\
\hline 11 & 哇 $w a$ & Menunjukan suara teriakan panik atau kesakitan. \\
\hline & &
\end{tabular}

Onomatope Suara Binatang

\begin{tabular}{|c|c|c|}
\hline No. & Onomatope & Makna \\
\hline 1 & 嘶 sī & $\begin{array}{l}\text { Menunjukkan bunyi kuda yang meringkik karena tali } \\
\text { kekangnya ditarik berlebihan. }\end{array}$ \\
\hline 2 & 汪 wăng & $\begin{array}{l}\text { Menirukan bunyi suara anjing yang sedang } \\
\text { menggongong. }\end{array}$ \\
\hline 3 & 嘶 sī & Menirukan bunyi suara ular berdesis. \\
\hline 4 & 砰吱 pēngzhī & $\begin{array}{l}\text { Menunjukan suara derap kaki badak yang sedang } \\
\text { berlari. }\end{array}$ \\
\hline 5 & 嘎哦 $g \bar{a} o ́$ & Menirukan bunyi suara gorila yang ingin menyerang. \\
\hline 6 & 嘎 $g \bar{a}$ & $\begin{array}{l}\text { Menirukan bunyi suara buaya yang sedang } \\
\text { membuka mulutnya. }\end{array}$ \\
\hline 7 & 嘎鸣 $g \bar{a} w \bar{u}$ & Menirukan bunyi suara buaya mengerang kesakitan. \\
\hline
\end{tabular}


Onomatope Suara Alam

\begin{tabular}{|l|l|l|}
\hline No. & \multicolumn{1}{|c|}{ Onomatope } & \multicolumn{1}{c|}{ Makna } \\
\hline 1 & 呼 hū & $\begin{array}{l}\text { Menunjukkan suara angin yang menghembus akibat } \\
\text { pintu gerbang yang ditutup. }\end{array}$ \\
\hline 2 & 沙沙 shāshā & $\begin{array}{l}\text { Menunjukan bunyi suara hujan turun dengan deras } \\
\text { dan suara arus air terjun atau sungai. }\end{array}$ \\
\hline 3 & 滴答滴答 dīdādīdō & $\begin{array}{l}\text { Menunjukan tetes-tetes air hujan yang terjatuh di } \\
\text { jalan. }\end{array}$ \\
\hline 4 & 呼 $h \bar{u}$ & $\begin{array}{l}\text { Menunjukan hembusan suara angin pada saat hujan } \\
\text { turun, suara angina kencang di atas gunung dan } \\
\text { suara angin dari api yang berkobar-kobar. }\end{array}$ \\
\hline
\end{tabular}

\section{Onomatope Suara Benda}

\begin{tabular}{|c|c|c|}
\hline No. & Onomatope & Makna \\
\hline 1 & 咣當 guāngdāng & $\begin{array}{l}\text { Menunjukkan adegan kuda yang berlari memisahkan } \\
\text { diri dengan gerobak penumpang, dan menunjukkan } \\
\text { suara seseorang yang membuka pintu secara tiba- } \\
\text { tiba dengan keras, serta berfungsi sebagai efek suara } \\
\text { seorang anak yang terjatuh saat sedang berlari }\end{array}$ \\
\hline 2 & 噠噠 $d \bar{a} d \bar{a}$ & $\begin{array}{l}\text { Menunjukkan suara gerobak penumpang yang } \\
\text { terguling setelah terpisah dari kuda yang } \\
\text { menariknya. }\end{array}$ \\
\hline 3 & 嗜 háo & $\begin{array}{l}\text { Menegaskan suara benda tajam yang ditusukkan ke } \\
\text { tubuh kuda. }\end{array}$ \\
\hline 4 & 嘎 $g \bar{a}$ & $\begin{array}{l}\text { Menunjukkan bunyi dari busur panah yang ditarik } \\
\text { seorang prajurit untuk memanah. }\end{array}$ \\
\hline 5 & 咣 guāng & $\begin{array}{l}\text { Menunjukkan suara anak panah yang dihalau } \\
\text { sehingga anak panah tersebut melesat ke langit. }\end{array}$ \\
\hline 6 & 哝哝 nóngnóng & $\begin{array}{l}\text { Menunjukkan bunyi dua anak panah yang } \\
\text { ditembakkan secara beruntun ke arah seorang } \\
\text { prajurit. }\end{array}$ \\
\hline 7 & 啪 $p \bar{a}$ & $\begin{array}{l}\text { Menunjukkan adegan seorang anak yang menangkap } \\
\text { wadah kue yang dilempar ke arahnya dengan kedua } \\
\text { tangan dan untuk menunjukkan suara pintu yang } \\
\text { ditutup. }\end{array}$ \\
\hline 8 & 唰 shuā & Memberikan efek suara pada topi yang dilempar. \\
\hline 9 & 咔嚓 $k \bar{a} c h \bar{a}$ & Untuk menguatkan suasana. \\
\hline 10 & 啪啪啪啪 $p \bar{a} p \bar{a} p \bar{a} p \bar{a}$ & $\begin{array}{l}\text { Berfungsi sebagai bunyi empat anak panah yang } \\
\text { menancap ke sebuah tiang mengelilingi kepala } \\
\text { seoranganak. }\end{array}$ \\
\hline 11 & 嗒 $d \bar{a}$ & $\begin{array}{l}\text { Menunjukkan suara langkah kaki kuda dan untuk } \\
\text { menunjukkan bunyi batu igo yang dipegang oleh } \\
\text { seseorang membentur papan permainan. }\end{array}$ \\
\hline 12 & 咯当咯当 gēdāng gēdāng & $\begin{array}{l}\text { Menunjukkan bunyi gerobak yang ditarik oleh } \\
\text { kerbau sedang berjalan menjauhi gerbang kota. }\end{array}$ \\
\hline
\end{tabular}




\begin{tabular}{|l|l|l|}
\hline 13 & 修鸣鸣 $x \bar{u} w \bar{w} w \bar{u}$ & Menunjukan suara roket. \\
\hline 14 & 哔毕 bìbì & Menunjukan suara satelit. \\
\hline 15 & 滋 $z \bar{I}$ & Menunjukan bunyi kertas foto tercetak. \\
\hline 16 & 咔嚓 kāchā & Menunjukan bunyi Mesin. \\
\hline 17 & 轰隆 hōnglóng & Menunjukan bunyi gemuruh mesin kapal. \\
\hline 18 & 隆隆 lónglóng & $\begin{array}{l}\text { Menunjukan bunyi suara gemuruh kapal, dan } \\
\text { menunjukan bunyi suara batu serta menunjukan } \\
\text { bunyi suara gemuruh kereta kuda. }\end{array}$ \\
\hline 19 & 丁 ding & Menunjukan suara pedang yang bergesekan. \\
\hline 20 & 当 dāng & Menunjukan suara pedang yang ditangkis. \\
\hline 21 & 砰滋 pēngzí & Menunjukan suara tembakan senjata. \\
\hline 22 & 哔嘶 bìsi & Menujukan suara pedang yang dikibas-kibaskan. \\
\hline
\end{tabular}

Onomatope Suara Bunyi Kegiatan Sehari-hari

\begin{tabular}{|c|c|c|}
\hline No. & Onomatope & Makna \\
\hline 1 & 铭 qiāng & $\begin{array}{l}\text { Memberikan kesan tajam pada pisau yang sedang } \\
\text { dipegang. }\end{array}$ \\
\hline 2 & 嚓 $c \bar{a}$ & $\begin{array}{l}\text { Menunjukkan bunyi saat tali pengait kuda terpisah } \\
\text { dengan gerobak penumpang. }\end{array}$ \\
\hline 3 & 吧嗒 $b \bar{a} d \bar{a}$ & $\begin{array}{l}\text { Menunjukkan bunyi seseorang yang dijatuhkan ke } \\
\text { lantai dengan posisi tengkurap. }\end{array}$ \\
\hline 4 & 嗉通 sùtōng & $\begin{array}{l}\text { Menunjukkan adegan kuda yang terjatuh ke sungai } \\
\text { dari jurang yang tinggi. }\end{array}$ \\
\hline 5 & 哔吵 bìshā & $\begin{array}{l}\text { Berfungsi sebagai suara air yang disiramkan ke arah } \\
\text { muka seorang anak. }\end{array}$ \\
\hline 6 & 擦擦 $c \bar{a} c \bar{a}$ & $\begin{array}{l}\text { Menunjukan suara langkah kaki di jalan basah } \\
\text { karena air hujan. }\end{array}$ \\
\hline 7 & 哒 dá & Menunjukan suara langkah kaki. \\
\hline 8 & 啪 $p \bar{a}$ & Menunjukan suara benda. \\
\hline 9 & 啪哒 pādá & Menunjukan suara pintu yang ditutup dengan keras. \\
\hline 10 & 碰 pèng & Menunjukan suara pintu yang dibuka. \\
\hline 11 & 嘭 pēng & Menunjukan suara pintu atap besi yang dibuka. \\
\hline 12 & 蓬蓬 péngpéng & $\begin{array}{l}\text { Menunjukan suara tumpukan kertas-kertas foto yang } \\
\text { terjatuh. }\end{array}$ \\
\hline 13 & 哒砰 dápēng & Menunjukan suara badak yang terjatuh. \\
\hline 14 & 啪咚 pādōng & Menunjukan bunyi benturan benda yang dilempar. \\
\hline 15 & 格勒 gélè & $\begin{array}{l}\text { Menunjukan suara batu-batu yang berjatuhan dan } \\
\text { menunjukan suara pedang yang terjatuh. }\end{array}$ \\
\hline 16 & 轰 hōng & $\begin{array}{l}\text { Menunjukan suara peluru dari kapal yang sedang } \\
\text { ditembakan untuk menghancurkan musuh. }\end{array}$ \\
\hline 17 & 砰隆 pénglóng & Menunjukan suara ledakan dari peluru. \\
\hline 18 & 砰砰 pēngpēng & $\begin{array}{l}\text { Menunjukan suara ledakan peluru-peluru dari } \\
\text { musuh yang ditembakan ke arah kereta kuda. }\end{array}$ \\
\hline 19 & 咯咚 gēdōng & Menunjukan suara roda pada mesin yang sedang \\
\hline
\end{tabular}


bergerak, menandakan mesin tersebut aktif.

\section{Onomatope Suara Alat Musik}

\begin{tabular}{|l|c|l|}
\hline No. & \multicolumn{1}{|c|}{ Onomatope } & \multicolumn{1}{c|}{ Makna } \\
\hline 1 & 咚唧唧 dōnglāng lāng & $\begin{array}{l}\text { Menunjukan bunyi suara gendang yang sedang } \\
\text { dimainkan. }\end{array}$ \\
\hline
\end{tabular}

\section{KESIMPULAN}

Onomatope memberikan kesan mendalam bagi sebuah karya karena mampu menghidupkan suasana dari isi karya tersebut. Komik yang dipadukan dengan unsur onomatope di dalamnya, membantu unsur gambar dan plot cerita menjadi lebih maksimal. Onomatope dalam komik menunjukkan bahwa dalam setiap sisi kehidupan manusia, terdapat bunyi yang memiliki makna tersendiri. Onomatope bahasa Mandarin dalam komik berhasil memberi informasi bahwa terdapat kata-kata onomatope bahasa Mandarin dalam aktivitas hidup manusia sehari-hari yang diwujudkan untuk mendeskripsikan tulis dari suara manusia, binatang, alam, benda, kegiatan sehari-hari dan alat musik. Onomatope bahasa Mandarin dalam komik memberikan kita pengetahuan terkait penulisan kosakata kata-kata onomatope dalam bahasa Mandarin di setiap aktivitas kehidupan manusia.

\section{DAFTAR PUSTAKA}

[1] Ashworth, J. (2012). Onomatopoeia and Pensonification: Budding Poets. Dayton: Lorenz Educational Press.

[2] Friska Langelo, D. P. (2015). ANALISIS PENERAPAN STANDAR AKUNTANSI PEMERINTAHAN BERBASIS AKRUAL DALAM PENYAJIAN LAPORAN KEUANGAN PADA PEMERINTAH KOTA BITUNG. Jurnal EMBA: Jurnal Riset Ekonomi, Manajemen, Bisnis dan Akuntansi, 1-8.

[3] MS, G. (2011). Comic Making Cara Membuat Komik. Jakarta: Indeks.

[4] Nurgiyantoro, B. (2018). Sastra Anak: Pengantar Pemahaman Dunia Anak. Yogyakarta: Gadjah Mada University Press.

[5] Putri, A. E. (2019). EVALUASI PROGRAM BIMBINGAN DAN KONSELING: SEBUAH STUDI PUSTAKA. Jurnal Bimbingan Konseling Indonesia, 39-42.

[6] Widi, R. K. (2010). Asas Metodologi Penelitian Sebuah Pengenalan dan Penuntun Langkah Demi Langkah Pelaksanaan Penelitian. Yogyakarta: Graha Ilmu. 